\title{
PATHOGENECITY OF GROUPER SLEEPY DISEASE IRIDOVIRUS (GSDIV: Megalocytivirus, FAMILY Iridoviridae) TO CORAL TROUT GROUPER Plectrophomus leopardus
}

\author{
Ketut Mahardika *, Ahmad Muzaki, and Ketut Suwirya \\ Research Institute for Mariculture
}

\begin{abstract}
Grouper sleepy disease iridovirus (GSDIV), a member of the genus Megalocytivirus in the family Iridoviridae, has been known to cause large scale mortalities resulting in severe economic losses in grouper industries in south-east Asia including Indonesia. In this study, experimental infection of coral trout grouper Plectrophomus indicus with GSDIV was performed to evaluate the viral pathogenecity to this fish species. After virus exposure, the mortalities of coral trout grouper injected with primary and $10^{-1}$ dilution of spleen homogenates derived from tiger grouper Epinephelus fuscoguttatus were $100 \%$ and $90 \%$, respectively. Histopathology revealed that moribund fish receiving GSDIV inoculum displayed massive formation of enlarged cells in the spleen and hematopoitic tissues. Under electron microscopy, the enlarged cells were observed as inclusion body bearing cells (IBCs) and necrotic cells allowing virus propagation within an intracytoplasmic virus assembly site (VAS). GSDIV virions were 167-200 nm in size. These findings confirmed that GSDIV has severe pathogenicity to coral trout grouper and IBCs as well as necrotic cells were determined to be the pathognomonic sign of megalocytivirus-infected coral trout grouper.
\end{abstract}

KEYWORDS: coral trout grouper, GSDIV, IBCs, Megalocytivirus, Necrotic cells

\section{INTRODUCTION}

The family Iridoviridae is currently classified into five genera i.e.: Iridovirus, Chloriridovirus, Ranavirus, Megalocytivirus, and Lymphocystivirus. The genus Megalocytivirus was newly established and encompasses several viral isolates such as grouper sleepy disease iridovirus (GSDIV), red sea bream iridovirus (RSIV), sea bass iridovirus (SBIV), African lampeye iridovirus (ALIV), dwarf gourami iridovirus (DGIV), Taiwan grouper iridovirus (TGIV), infectious spleen and kidney necrosis virus (ISKNV), which are genetically identical (Chinchar et al., 2005). In the first, epizootic caused by megalocytivirus occurred among red sea bream in 1990 (Inouye et al., 1992). Subsequently, outbreaks of megalocytivirus disease have been recorded in a total of 31 cultured marine fish species in 18 prefectures located in south-western part of Japan (Kawakami \& Nakajima, 2002). The same outbreaks were reported in brown-spotted grouper Epinephelus tauvina in Singapore in 1992 (Chua et al., 1994), Malabar grouper E. malabaricus and sea bass Lateolabrax spp. in southern Thailand in 1993 (Danayadol et al., 1996), groupers (Epinephelus spp.) and hybrid grouper (red spotted grouper E. akaara $x$ Malabar grouper) in Taiwan (Chou et al., 1998; Chao et al., 2002). Similar megalocytivirus has

\# Corresponding author. Research Institute for Mariculture. Jl. Br. Gondol, Kec. Gerokgak, Kab. Buleleng, Kotak Pos 140, Singaraja, Bali 81101 , Indonesia. Tel.: (0362) 92278, Fax. (0362) 92272/71 E-mail address: 
been identified from beakperch Oplegnathus fasciatus and rockfish Sebastes schlegeli cultured in Korea Jung \& Oh, 2000; Kim et al., 2002), large yellow croaker Larimichthys crocea (Chen et al., 2003), red drum Sciaenops occelatus (Weng et al., 2002) and turbot Scophthalmus maximus (Shi et al., 2004) cultured in China. In ornamental freshwater fishes, megalocytivirus has also been isolated from diseased African lampeye Aplocheilichthys normani that were cultured on Sumatra Island and exported to Japan (Sudthongkong et al., 2002a), dwarf gourami Colisa lalia that were exported to Australia from Singapore (Anderson et al., 1993; Go \& Whittington, 2006), orange chromide cichlid Etroplus maculatus exported to Canada from Singapore (Armstrong \& Ferguson, 1989), angelfish Pterophyllum scalare in UK (Rodger et al., 1997), and gourami and swordtail Xiphophorus hellerii in Israel (Paperna et al., 2001), which were bred in those countries after being imported from Singapore. A diagnostic feature of megalocytivirus disease is the formation of inclusion body-bearing cells (IBCs) as well as necrotized cells, both of which are observed as enlarged cells by light microscopy (Miyazaki, 2007).

Groupers are major mariculture fish species in Indonesia. Recently, the viral diseases have caused severe epizootics resulting in mass mortalities and large-scale economic losses. GSDIV has caused mass mortality of orangespotted grouper E. coioides cultured in pencages off North-Sumatra Island (Koesharyani et al., 2001), orange-spotted grouper and Bleeker's grouper E. bleekeri cultured in pens offshore of Bali Island (Mahardika et al., 2001), and broodstock of orange-spotted grouper stocked in broodstock tanks of Bali Island (Mahardika et al., 2003). GSDIV has also been shown to infect other groupers such as the humpback grouper Cromileptes altivelis (Mahardika et al., 2004a), marbled grouper $E$. polyphekadion (Mahardika et al., 2004b) and tiger grouper $E$. fuscoguttatus (Mahardika, unpublished data). In the present study, infection experiments were performed to examine the pathogenicity of GSDIV to coral trout grouper as this is a new cultured grouper species with high commercial value for the development of mariculture in Indonesia. A tissue filtrate was obtained from tiger grouper moribund with the GSDIV infection and was given as inocula at different concentrations of the virus. This paper describes the results of the infec- tion experiments and detail electron microscopic observation of enlarged cells produced in coral trout-infected megalocytivirus.

\section{MATERIAL AND METHODS}

\section{Experimental fish}

A total of 65 coral trout grouper (mean body weight, $5 \mathrm{~g}$ ) were obtained from Gondol Research Institute for Mariculture, Bali. Five samples of these were examined by PCR assay using a primer set for SJNNV (striped jack nervous necrosis virus) (Nishizawa et al., 1994) and for Pst I restriction fragment of RSIV genomic DNA (Kurita et al., 1998) and all were negative for the presence of NNV (nervous necrosis virus: Betanodavirus) and megalocytivirus.

\section{Virus inoculum}

The GSDIV inoculum used in the experimental infections was derived from the spleens of tiger groupers that were experimentally infected with a spleen filtrate which originated from orange-spotted grouper with grouper sleepy disease (GSD). The spleens were stored at $-80^{\circ} \mathrm{C}$ after all of the spleen samples were confirmed positive for GSDIV by PCR (see below). For the challenge tests the spleen tissue was homogenized in 10x vol of Eagle's minimum essential medium (EMEM) supplemented with $2 \%$ fetal bovine serum in a glass homogenizer. The homogenate was centrifuged at $3,000 \mathrm{rpm}$ for $15 \mathrm{~min}$ at $4^{\circ} \mathrm{C}$, and the supernatant was harvested and filtered $(450 \mathrm{~nm})$. This method was chosen because of difficulties in obtaining the in vitro cultured virus (lack of facilities for virus culture).

\section{Challenge tests}

We prepared 2 inocula to obtain different concentrations of GSDIV, one consisting of the primary filtrate $\left(10^{\circ}\right)$ and the other of a $10^{-1}$ dilution. A $0.1 \mathrm{~mL}$ inoculum was injected intramuscularly into the fish. A control fish was given only Eagle's minimum essential medium (EMEM) supplemented with $2 \%$ fetal bovine serum. One experiment was conducted with 20 fish per group. The fish were held in tanks ( $200 \mathrm{~L}$ at $28^{\circ} \mathrm{C}$ to $31^{\circ} \mathrm{C}$ ) with aeration and daily water exchange. They were fed upon commercial pellets. Moribund and dead fish were removed from the tanks, dissected and samples were processed for laboratory exami- 
nation. At the end of the experiment, all surviving fish were dissected for subsequent laboratory examination.

\section{Histophatological and electron microscopic examinations}

Tissue samples (whole body) were fixed in Bouin's fluid ( $15 \mathrm{~mL}$ picric acid, $5 \mathrm{~mL}$ of $37 \%$ formaldehyde solution containing $8 \%$ methanol, $1 \mathrm{~mL}$ acetic acid) for histopathological examination. Further samples of the spleen tissue were fixed in 70\% Karnovsky's solution ( $1.6 \mathrm{~g}$ paraformaldehyde in $20 \mathrm{~mL}$ distilled water, $2 \mathrm{~mL}$ of $70 \%$ glutaraldehyde, $35 \mathrm{~mL}$ of $0.2 \mathrm{M}$ $\mathrm{PBS}, 13 \mathrm{~mL}$ distilled water), post-fixed in $1 \% \mathrm{OsO}_{4}$ and processed for examination by electron microscopy as described previously by Mahardika et al. (2008).

\section{PCR Analysis}

PCR analysis to test for the presence of GSDIV in fish tissues was undertaken using primers 1-F (5'-CTCAAACACTCTCGCTCATC-3') and $1-\mathrm{R}$ (5' GCACCAACACATCTCCTATC-3'), which were derived from the DNA sequence of the 959-bp Pst I fragment of RSIV (Kurita et al., 1998). Using this PCR test, amplification products of about $570 \mathrm{bp}$ are generated. As well as the virus inoculum, the spleens of 5 moribund fish in the primary and $10^{-1}$ dilution group, and 5 surviving fish in the control group were processed for PCR analysis. DNA templates were extracted from about $10 \mathrm{mg}$ of spleen tissue using ISOGEN (Wako Nippon Gene, Osaka, Japan) according to the manufacturer's protocol. The PCR amplification was performed under conditions described previously by Kurita et al. (1998).

\section{RESULTS AND DISCUSSION}

\section{Mortality}

Daily mortalities of the treated fish are shown in Figure 1. In the group of fish was given the primary filtrate inoculum, mortality began $9 \mathrm{~d}$ after injection, reaching 100\%, respectively, within $13 \mathrm{~d}$. In the group was given an inoculum of $10^{-1}$ dilution, mortality began 8 $\mathrm{d}$ after injection, reaching $90 \%$, respectively, within $14 \mathrm{~d}$. In contrast, no mortality occurred in control group. None of the remaining fish died before the end of the experiment.

Diseased fish usually displayed lost of appetite and sleepy behavior. All moribund fish displayed a slight dark coloration on the body and a markedly swollen spleen (Figure $2 \mathrm{~A} \&$ 2B). The surviving fish which received the $10^{-2}$ diluted inoculum and control groups did not display sleepy behavior and maintained a good appetite until the end of the experiment.

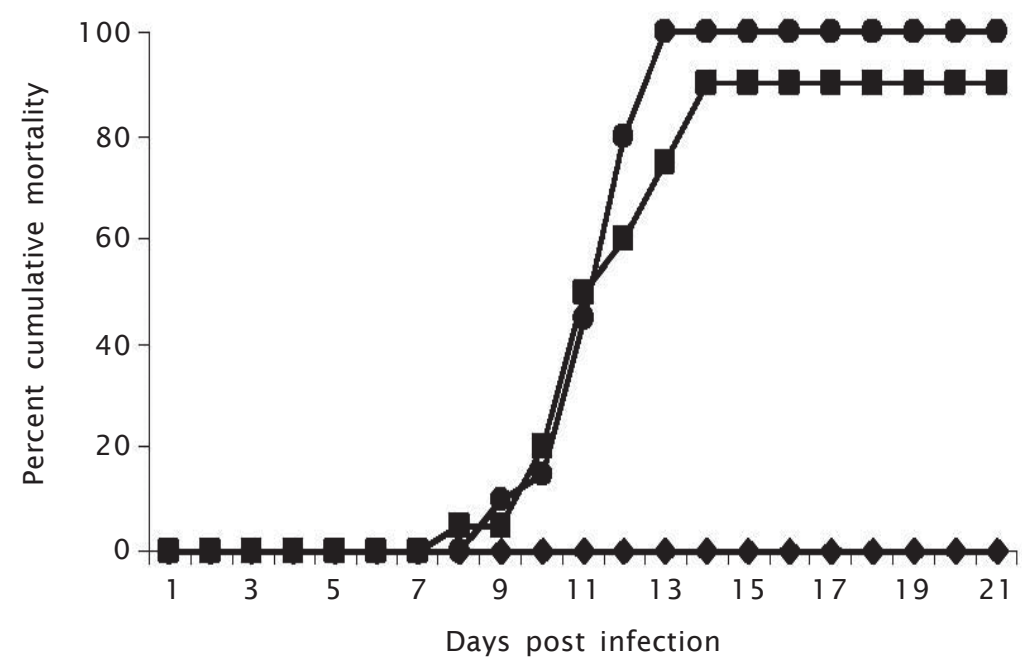

Figure 1. Cumulative mortality of juvenile coral trout grouper injected with primary filtrate $(=), 10^{-1}$ dilution $(<)$ of spleen homogenate derived from GSDIV-infected tiger grouper at $28^{\circ} \mathrm{C}-31^{\circ} \mathrm{C}$ for 21 days. No mortalities occurred in control group (u), injected with MEM-2 

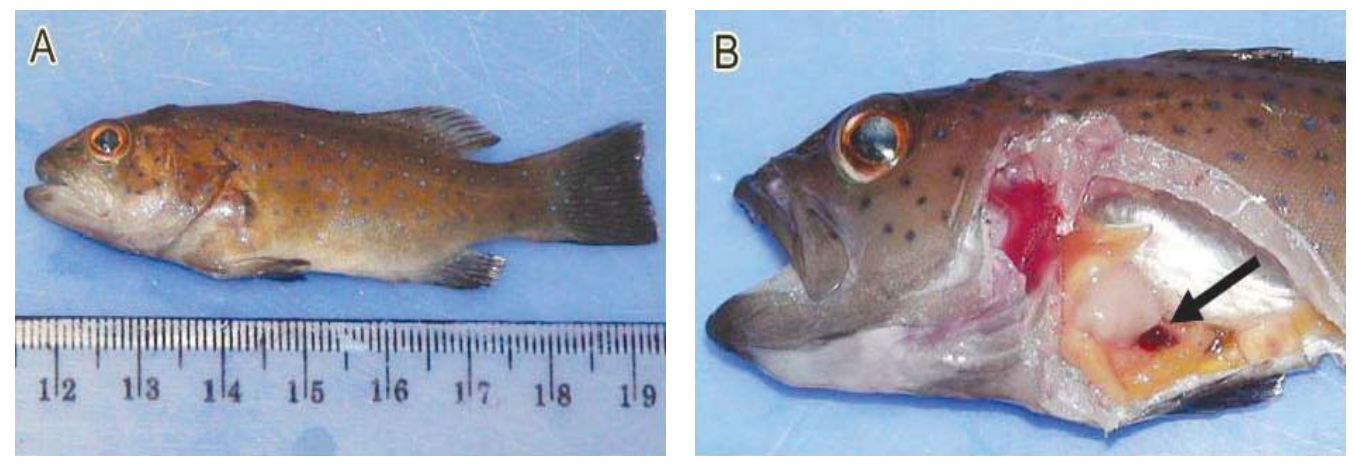

Figure 2. (A) Moribund fish with a slight dark coloration of the body. (B) Dissected moribund fish with markedly swollen spleen (arrow)

The spleen is known to be a major target organ of megalocytivirus-infection, and this organ is often used for a tissue filtrate of virusinfected fish to determine viral pathogenicity and fish susceptibility to disease (Nakajima \& Sorimachi, 1994; Chao et al., 2004; Mahardika et al., 2004a; 2008; Go \& Whittington, 2006). The viral inoculum prepared from grouper spleen contained megalocytivirus based on PCR assays using the primer set that were derived from a Pst I restriction fragment of RSIV genomic DNA (Kurita et al., 1998). Taking this data and the observed sleepy behavior, the causative megalocytivirus was confirmed to be GSDIV.

\section{Histopathological signs}

In histological observation, all of moribund fishes showed the systemic formation of enlarged cells as well as necrotized of splenocytes (Figure 3A). Enlarged cells also appeared in the hematopoietic tissues of kidney (Figure 3B), while few enlarged cells were observed in the liver and digestive tracts. No control fish showed any histopathological changes or formation of enlarged cells (Figure 3C \& 3D).

Present experimental infection revealed that GSDIV isolated from experimental tiger grouper had severe pathogenicity to coral trout grouper. Histopathological observation revealed the primary change occurred in the spleens: formation of enlarged and necrotic of splenocyte cells, which displayed GSDIV-infection with electron microscopy. The viruses released from these infected cells spread through the circulatory system to infect other organs such as kidney, liver, and digestive tracts. Results of our studies resembled results of studies by Chao et al. (2004) who showed that the pathogenesis of Taiwan grouper iridovirus (TGIV, Megalocytivirus) begin with a first replication in the spleen, resulting in an increased number of basophilic enlarged cells in the spleen. Then, the virus-infected cells released and spread to other organs, especially the trunk kidney and head kidney. Moreover, they reported that a consequence of the presence of enlarged cells in the circulatory system, these cells are trapped in the capillaries, especially in the gills, resulting in insufficient gas exchange and finally in the death of the fish. The dead fish caused by lacking in gas exchange might be true, however in the present results severe necrosis of splenocytes due to the GSDIV infection contribute of diseased fish to die.

\section{Electron microscopic features}

Electron microscopy (EM) examination of the spleen of moribund fish revealed enlarged cells were cells forming an intracytoplasmic inclusion body as termed inclusion body bearing cells (IBCs) and necrotic cells (Figure 4A). IBCs had an intracytoplasmic inclusion body, which was delimited from the host-cell cytoplasm by a thin membranous boundary. IBCs had a markedly enlarged inclusion body containing a developed VAS, many of mitochondria, smooth endoplasmic reticula (sER) and ribosome, and masses of granules (Figure 4B4D). The host cell cytoplasm and nucleus were marginally compressed. The inclusion bodies had the centrally located VAS allowing propagation of multiple virus particles (Figure 5A). 

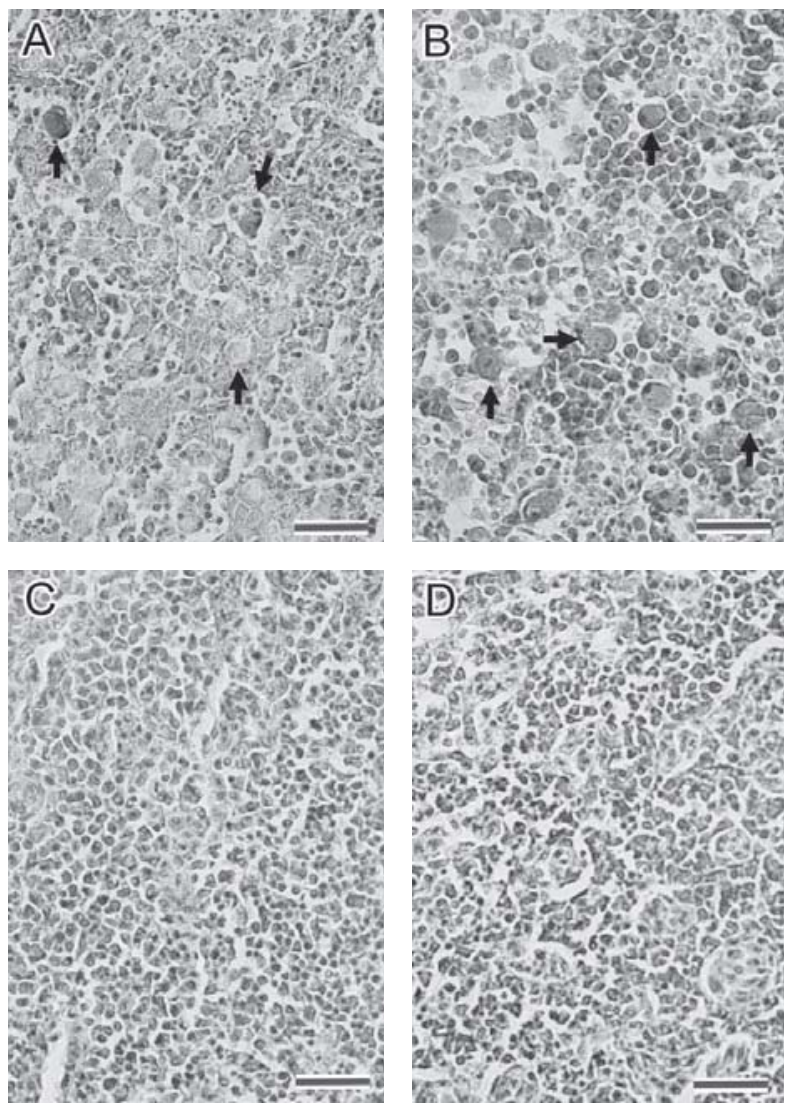

Figure 3. (A) Spleen of moribund fish injected with primary filtrate shows massive formation of enlarged cells (arrows) and necrotized plenocytes (H\&E; scale bar $=50 \mathrm{um}$ ). (B) Kidney of moribund fish injected with $10^{-2}$ diluted filtrate shows many enlarged cells (arrows) in the hematopoietic tissue (H\&E; scale bar= $50 \mathrm{um}$ ). (C) Spleen of surviving fish in control group shows healthy splenocyte cells (H\&E; scale bar= $50 \mathrm{~mm}$ ). (D) Kidney of surviving fish in control group shows healthy hematopoitic cells (H\&E; scale bar $=50$ um)

The VAS had an electron-lucent matrix with abundant fine granules, microfilaments and hexagonal virions, which $167-200 \mathrm{~nm}$ in size, comprise, in turn, a complete package of an electron-dense core within the capsid (Figure 5B).

As well as IBCs, necrotized of splenocyte cells were also observed in moribund fish. This cell just formed intracytoplasmic VAS without the formation of the distinct inclusion body. In the VAS, large numbers of virions were assembled (Figure 5C). No control fish showed any formation of IBCs or necrotic cells containg virions (Figure 5D).
By electron microscopic examination, the enlarged cells seen in GSDIV-infected coral trout grouper were determined to be IBCs, which were similar to those seen in megalocytivirus-infected red sea bream, dwarf gourami, African lampeye, sea bass and humpback grouper (Jung et al., 1997; Sudthongkong et al., 2002 a,b; Mahardika et al., 2004a; 2008; Miyazaki, 2007) as well as megalocytivirus-infected GF (grunt fin) cells, in vitro (Mahardika \& Miyazaki, 2009). Thus, the result of present study confirmed that the IBCs were derived from GSDIV-infected coral trout grouper and the formation of IBCs was a pathognomonic 

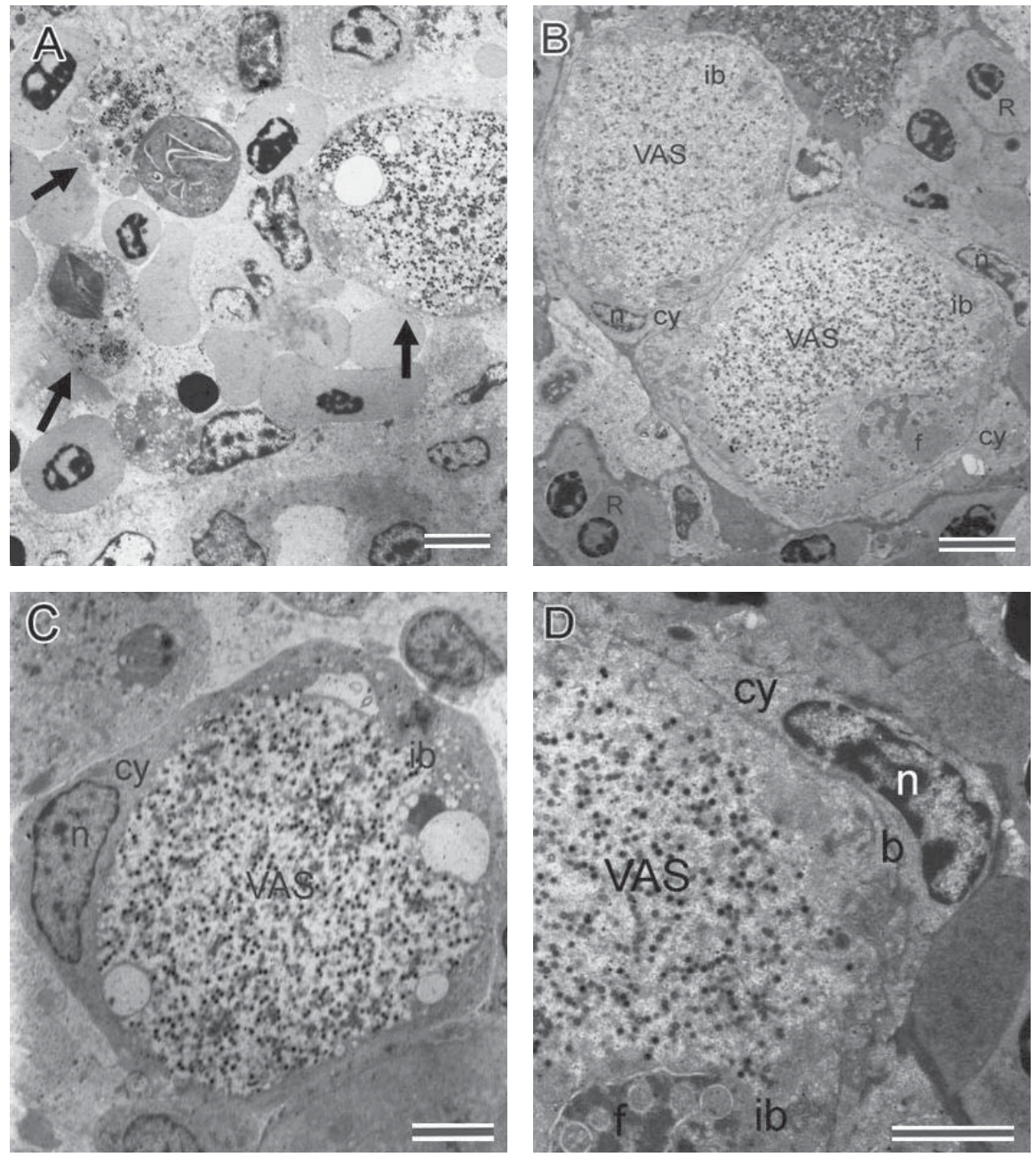

Figure 4. Electron micrograph of spleen tissue of moribund fish. (A) Spleen tissue contain inclusion body-bearing cell (IBC) and necrotic splenocyte cells with multiple virions (arrows) (scale bar $=3,600 \mathrm{~nm}$ ). (B) Two IBCs with large inclusion body containing masses of fine granules ( $f$ ) beside developed virus assembly site (VAS) with many virions (scale bar $=4,500$ $\mathrm{nm}$ ). (C) IBC with enlarged inclusion body; developed VAS contains large number of virions; degenerated mitochondria and vacuole are present beside VAS (scale bar $=3,300 \mathrm{~nm}$ ). (D) Detail of inclusion body of IBC shown in Figure 4B; an intracytoplasmic inclusion body was delimited from the host-cell cytoplasm by a thin membranous boundary (b); VAS contains many virions (scale bar $=1,500 \mathrm{~nm}$ ). b: boundary membrane; Cy: cytoplasm of host cell; $f$ : mass of fine granules; ib: inclusion body; $n$ : nucleus of host cell; R: red blood cell; VAS: virus assembly site

sign of megalocytivirus infection. In the previous studies, because the presence of intracytoplasmic inclusion body has not been precisely identified, IBCs have been variously termed amoeba-like organisms (Anderson et al., 1993), hypertrophic cells (Armstrong \& Ferguson, 1989), heteromorphic balloon cells (Inouye et al., 1992) and circumscribed bod- 

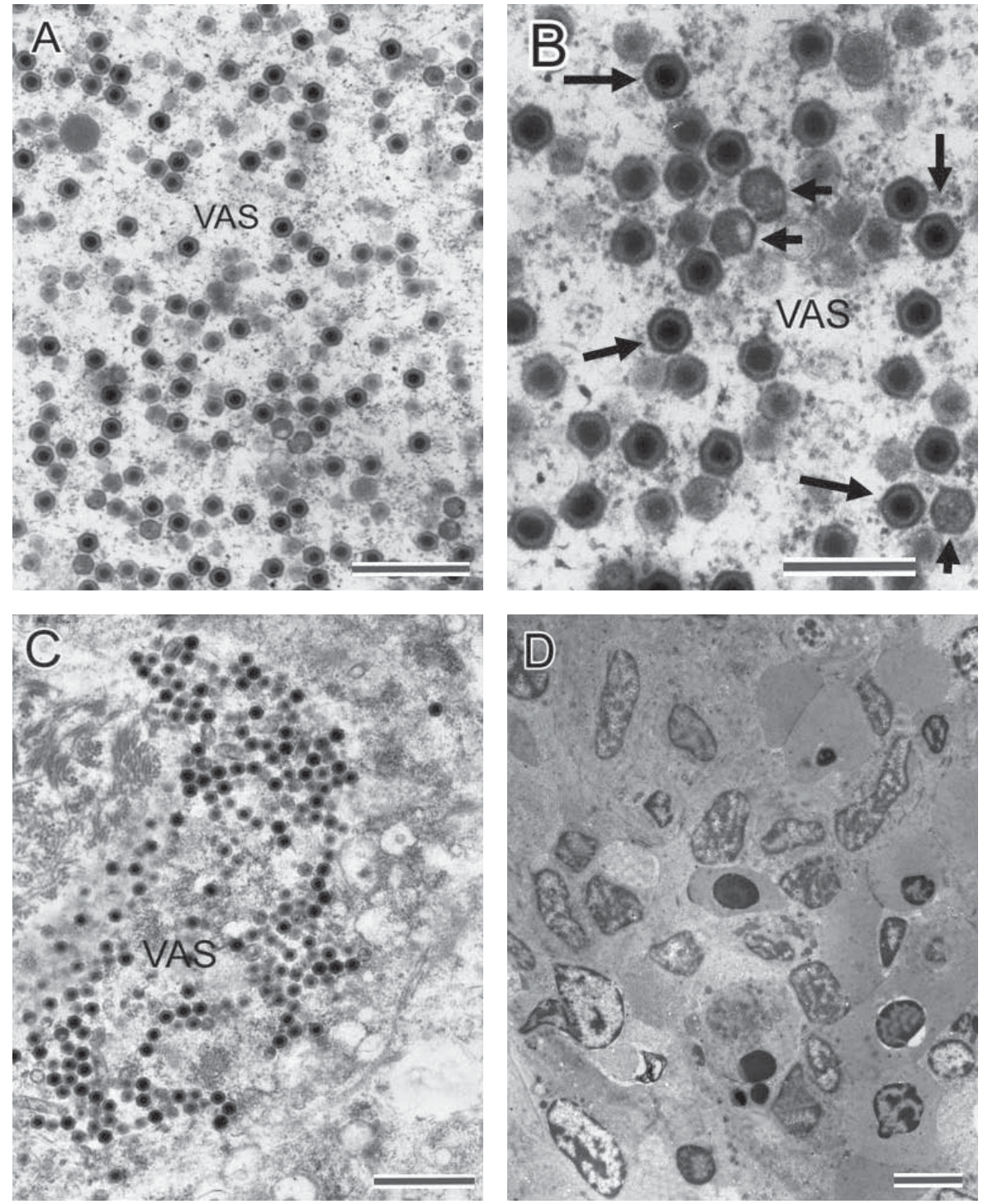

Figure 5. Electron micrograph of spleen tissue of moribund fish. (A) High-power view of viral assembly site (VAS). It contains fine granules and microfilaments with assembly of GSDIV virions (scale bar $=870 \mathrm{~nm}$ ). (B) Detailed features of virus particles at all stages of morphogenesis within the VAS of IBC. There are immature or partially-filled virions (short arrows) and mature or completely filled virions (large arrows) with the size of 167 to $200 \mathrm{~nm}$ (scale bar $=600 \mathrm{~nm}$ ). (C) A splenocyte infected with GSDIV is necrotized with propagation of GSDIV in the cytoplasm. This type of cell just forms intracytoplasmic VAS, in which many virions are assembled, without the formation of distinct inclusion body. The nucleus has disappeared (scale bar $=2,000 \mathrm{~nm}$ ). (D) Electron micrograph of spleen tissue of surviving fish in control group. This tissue is free from IBCs and necrotized of splenocyte cells with GSDIV virions (scale bar $=3,600 \mathrm{~nm}$ ). Abbreviations as in Figure 4 
ies (Chua et al., 1994). The progression of cellular change in the hypertrophic cells of chromide cichlid (Armstrong \& Ferguson, 1989) was the same as that of IBCs. As does Jung et al. (1997), Sudthongkong et al. (2002 a,b), Mahardika et al. (2004, 2008, 2009), and Miyazaki (2007), we use the term 'inclusion body-bearing cells' because the iridovirus-infected cells notably formed an inclusion body within the cytoplasm. In IBCs, the inclusion bodies are composed of virions, rER, sER, ribosomes, mitochondria and the granular masses that contains DNA. Similar granular masses of enlarged cells of TGIV-infected grouper was revealed to contain TGIV DNA by in situ hybridization using DNA probes for TGIV by Chao et al. $(2002,2004)$. The inclusion body of IBCs was completed for the propagation of large numbers of virions. It is thought that the IBCs observed in the spleen, kidney, liver, gills, and heart of infected fish are cells of the macrophage/monocyte lineage (Miyazaki, unpublished observations). TGIV infection inhibited normal phagocytic ability in these cells in vivo, in which by staining properties and phagocytic ability suggested a monocyte origin of enlarged cells, which appeared in high numbers in the spleen, trunk kidney, head kidney, and gill (Chao et al., 2004). In recent studies examining RSIV-infected grunt fin cells demonstrated the presence of inclusion bodies in vitro (Mahardika \& Miyazaki, 2009) and in vitro results to eliminate the possibility that they are an in vivo phenomenon that results when host macrophages engulf a virus infected cell. However, it remains to be determined if assembly site formation among megalocytiviruses is a fundamentally different process from that seen among other iridovirids or whether the generation of inclusion body-bearing cells represents the engulfment of infected cells by neighboring cells (apoptosis process) or entosis process (Overholtzer et al., 2007). Necrotized of splenocyte cells were also observed in moribund fish. This cell just formed intracytoplasmic VAS with marked propagation of virions. Thus, GSDIV-infected splenocytes of coral trout grouper were not only IBCs but also necrotized cells.

\section{PCR assay}

PCR products were obtained from the moribund fish that were examined from fish receiving both primary and $10^{-1}$ dilution filtrate inoculum. On the other hand, PCR amplicons of the predicted size were not derived from the DNA extracts of the spleens of the surviving fish from the control group (Figure 6).

In summery, in the present study, we revealed the pathogenicity test of GSDIV to coral trout grouper and observed the ultrastructural features of enlarged cells that derived from GSDIV-infected coral trout grouper. This is first report of experimental infection of GSDIV-infected coral trout resulted in higher mortality and induced IBCs as well as necrotic cells and to be similar as those shown in megalocytivirus-infected fish (in vivo) and cultured cells (in vitro). Further studies are needed

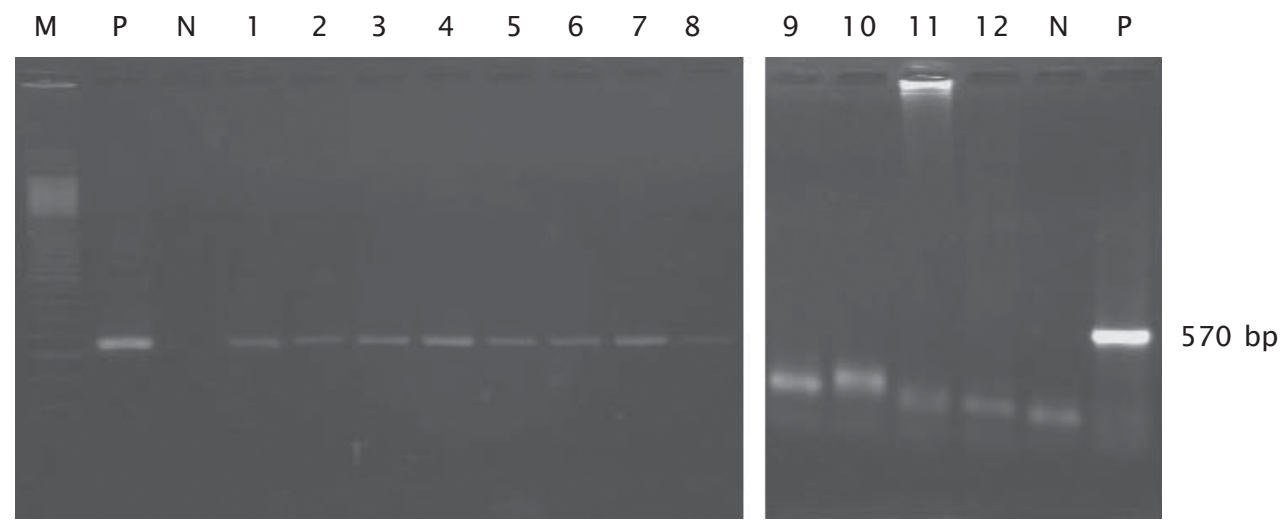

Figure 6. Putative PCR amplicons derived from DNA extract of the spleens of moribund fish injected with primary filtrate (lane: 1 to 4 ) and $10^{-1}$ dilution (lane: 5 to 8 ), and surviving fish in control group (lane: 9 to 12). M: marker, P: positive control, N: negative control 
to determine the potential risk of GSDIV in other fish species important to aquaculture industries and developed vaccine which have potency to inhibited both megalocytivirus-infected marine and fresh water fishes.

\section{ACKNOWLEDGEMENTS}

We would like to thank Professor Dr. Teruo Miyazaki of Graduate School of Bioresources Mie University, Japan for his valuable suggestions and helpful comments on this paper. We also thank Dr. Haryanti and all staffs of the Biotechnology Lab., Gondol Research Institute for Mariculture, Bali for helpful suggestions and their assistance with the experimental infection.

\section{REFERENCES}

Anderson, I.G., Prior, H.C., Rodwell, B.J., \& Harris, G..O. 1993. Iridovirus-like virions in imported dwarf gourami (Colisa lalia) with systemic amoebiasis. Aus. Vet. J., 70: 66-67.

Armstrong, R.D. \& Ferguson, H.W. 1989. Systemic-viral disease of the chromide cichlid Etroplus maculates. Dis. Aquat.Org., 7: 155157.

Chao, C.B., Yang, S.C., Tsai, H.Y., Chen, C.Y., Lin, C.S., \& Huang, H.T. 2002. A nested PCR for the detection of grouper iridovirus in Taiwan (TGIV) in cultured hybrid grouper, giant seaperch, and largemouth bass. J. Aquat. Anim. Health, 14:104-113.

Chao, C.B., Chen, C.Y., Lai, Y.Y., Lin, C.S., \& Huang, H.T. 2004. Histological, ultrastructural, and in situ hybridization study on enlarged cells in grouper Epinephelus hybrids infected by grouper iridovirus in Taiwan (TGIV). Dis. Aquat. Org., 58: 127-142.

Chen, X.H., Lin, K.B., \& Wang, X.W. 2003. Outbreaks of an iridovirus disease in maricultured large yellow croaker, Larimichthys crocea (Richardson), in China. J. Fish Dis., 26: 61 5-619.

Chinchar, G.., Essbauer, S., He, J.G.., Hyatt, A., Miyazaki, T., Seligy, V., \& Williams, T. 2005. Family Iridoviridae. In: Fauquet,C.M., M.A. Mayo, J. Maniloff, U. Desselberger, and L.A. Ball (Eds.) Virus Taxonomy. Classification and Nomenclature of Viruses. Eighth Report of the International Committee on the Taxonomy of Viruses. Academic Press, San Diego, p. 145-162.

Chou, H.Y., Hsu, C.C., \& Peng, T.Y. 1998. Isolation and characterization of a pathogenic iridovirus from cultured grouper (Epinephelus sp.) in Taiwan. Fish Pathol., 33: 201-206.

Chua, F.H.C., Ng, M.L., Ng, K.L., Loo, I.J., \& Wee, J.Y. 1994. Investigation of outbreaks of a novel disease, 'sleepy grouper disease', affecting the brown-spotted grouper Epinephelus tauvina Forskal. J. Fish Dis., 17: 417-427.

Danayadol, Y., Direkbusarakom, S., Boonyaratpalin, S., Miyazaki, T., \& Miyata, M. 1997. Iridovirus infection in brown-spotted grouper (Epinephelus malabaricus) cultured in Thailand. In: Flegel, T.W. and I.H. MacRae (Eds.) Diseases in Asian Aquaculture. III. Asian Fisheries Society, Manila, p. 67-72.

Go, J. \& Whittington, R. 2006. Experimental transmission and virulence of a megalocytivirus (Family Iridoviridae) of dwarf gourami (Colisa lalia) from Asia in Murray cod (Maccullochella peelii peelii) in Australia. Aquaculture, 258: 140-149.

Inouye, K., Yamano, K., Maeno, Y., Nakajima, K., Matsuoka, M., Wada, Y., \& Sorimachi, M. 1992. Iridovirus infection of cultured red sea bream, Pagrus major. Gyobyo Kenkyu, 27: 19-27.

Jung, S.J., Miyazaki, T., Miyata, M., Danayadol, Y., \& Tanaka, S. 1997. Pathogenicity of iridovirus from Japan and Thailand for the red sea bream Pagrus major. Fish Sci., 63: 735-740.

Jung, S.J. \& Oh, M.J. 2000. Iridovirus-like infection associated with high mortalities of striped beakperch, Oplegnathus fasciatus (Temminck et Schlegel), in southern coastal areas of the Korean Peninsula. J. Fish Dis., 23: 223-226.

Kawakami, H. \& Nakajima, K. 2002. Cultured fish species affected by red sea bream iridoviral disease from 1996 to 2000 . Fish Pathol., 37: 45-47 (in Japanese with English abstract).

Kim, Y.J., Jung, S.J., Choi, T.J., Kim, H.R., Rajendran, K.V., \& Oh, M.J. 2002. PCR amplification and sequence analysis of irido-like virus infecting fish in Korea. J. Fish Dis., 25: 121-124.

Koesharyani, I., Roza, D., Mahardika, K., Johnny, F., Zafran, \& Yuasa, K. 2001 . Iridovirus. In: Sugama, K., H. Ikenoue, and S. Kawahara (Eds.) Manual for Fish Disease Diagnosis-II. Marine fish and crustacean diseases in Indonesia. Gondol Marine Research for Mariculture, Central Research Institute for Sea 
Exploration and Fisheries, Dep of Marine Affair and Fisheries, and Japan International Cooperation Agency, p. 5-7.

Kurita, J., K. Nakajima, I. Hirono, and T. Aoki. 1998. Polymerase chain reaction (PCR) amplification of DNA of red sea bream iridovirus (RSIV). Fish Pathol., 33: 17-23.

Mahardika, K., Koesharyani, I., Sugama, K., Priyono, A., \& Yuasa, K. 2001. Histopathological study of iridovirus infection in Epinephelus coioides and Epinephelus bleekeri. In: Sugama, K., H. Ikenoue, and S. Kawahara (Eds.). Proceedings of Mariculture Technology and Sea Farming Development. Jakarta, Indonesia. Japan International Cooperation Agency, Jakarta, p. 334-341 (in Indonesian with English abstract).

Mahardika, K., Koesharyani, I., Prijono, A., \& Yuasa, K. 2003. Iridovirus infection of orange-spotted grouper (Epinephelus coioides) broodstock. Indonesian Research Sea Farming Journal, Aquaculture Edition, 9: 11-15 (in Indonesian with English abstract).

Mahardika, K., Zafran, Yamamoto, A., \& Miyazaki, T. 2004a. Susceptibility of juvenile humpback grouper (Cromileptes altivelis) to grouper sleepy disease iridovirus (GSDIV). Dis. Aquat. Org., 59: 1-9.

Mahardika, K., Zafran, Roza, D., \& Johnny, F. $2004 \mathrm{~b}$. Susceptibility test of the orange spotted grouper, Epinephelus coioides and marbled grouper, Epinephelus microdon to the iridovirus infection. J. Penelitian Perikanan Indonesia, 10(2): 83-88 (in Indonesian with English abstract).

Mahardika, K., Haryanti, Muzaki, A., \& Miyazaki, T. 2008. Histopathological and ultrastructural features of enlarged cells of humpback grouper Cromileptes altivelis challenged with Megalocytivirus (Family Iridoviridae) after vaccination. Dis. Aquat. Org., 79: 163-168.

Mahardika, K. \& Miyazaki, T. 2009. Electron microscopic features of cultured grunt fin cells infected with Megalocytivirus. Aquaculture Sci., 57(1): 9-18.

Miyazaki, T. 2007. Color Atlas of Fish Histopathology, Vol. 2. Shin-Suisan Shimbun-Sha, Tokyo, Japan, p. 325-335.
Nakajima, K. \& Sorimachi, M. 1994. Biological and physico-chemical properties of the iridovirus isolated from cultured red sea bream, Pagrus major. Fish Pathol., 29: 2933.

Nishizawa, T., Mori, K., Nakai, T., Furusawa, I., \& Muroga, K. 1994. Polymerase chain reaction (PCR) amplification of RNA of striped jack nervous necrosis virus (SJNNV). Dis. Aquat.Org., 18: 103-107.

Overholtzer, M., Mailleaux, A.A., Mouneimne, G., Normand, G., Schnitt, S.J., King, R.W., Cibas, E.S., \& Brugge, J.S. 2007. A nonapoptotic cell death process, entosis, that occurs by cell-in-cell invasion. Cell,131: 966-979.

Paperna, I., Vilenkin, M., \& Matos, A.D. 2001. Iridovirus infections in farm reared tropical ornamental fish. Dis. Aquat. Org., 48: 17-25.

Rodger, H.D., Kobs, M., Macarthney, A., \& Frerichs, G..N. 1997. Systemic iridovirus infection in freshwater angelfish, Pterophyllum scalare (Lichtenstein). J. Fish Dis., 20: 69-72.

Shi, C.Y., Wang, Y.G.., Yang, S.L., Huang, J., \& Wang, Q.Y. 2004. The first report of an iridovirus-like agent infection in farmed turbot, Scophthalmus maximus, in China. Aquaculture, 236: 11-25.

Sudthongkong, C., Miyata, M., \& Miyazaki, T. 2002a. Iridovirus disease in two ornamental tropical freshwater fishes: African lampeye and dwarf gourami. Dis. Aquat. Org., 48: 163-173.

Sudthongkong, C., Miyata, M., \& Miyazaki, T. $2002 \mathrm{~b}$. Viral DNA sequences of genes encoding the ATPase and the major capsid protein of tropical iridovirus isolates which are pathogenic to fishes in Japan, South China Sea and southeast Asian countries. Arch. Virol., 147: 2,089-2,109.

Weng, S.P., Wang, Y.Q., He, J.G.., Deng, M., Lu, L., Guan, H.J., Liu, Y.J., \& Chan, S.M. 2002. Outbreaks of an iridovirus in red drum, Sciaenops ocellata (L.), cultured in southern China. J. Fish Dis., 25: 681-685. 